\title{
Fundamentación de la pena necesaria y modelo de Estado
}

\author{
Aleyda Ulloa UlloA
}

\section{RESUMEN}

El castigo y sus métodos, al igual que el desarrollo de la noción de pena necesaria, se apoyan en el acontecer histórico y generan discursos que responden al modelo de Estado adoptado o que se pretenda adoptar, lo cual evidencia que la necesidad de pena como límite al poder punitivo adquiere mayor relevancia en modelos en los que la dignidad humana ocupa un lugar preeminente y parten del reconocimiento de los derechos del hombre; mientras que, a partir de prácticas donde el castigo resulta desproporcionado e "inhumano" se construye un discurso justificativo paralelo.

PALABRAS CLAVE: necesidad de pena, pena, derecho penal, derecho de castigar.

Fecha de recepción: febrero 3 de 2010

Fecha de aceptación: abril 6 de 2010

\section{ABSTRACT}

The punishment and its methods, as well as the development of the notion of a necessary pain, lean on historical events and generate speeches that respond to the model of State that is implemented or tried to be implemented; this shows that the need of pain as a limit to the punitive power acquires bigger relevance in models where the human dignity takes a pre-eminent position and start from the recognition of the man's rights; on the other hand, practices where the punishment is disproportionate and inhuman build a parallel justifying speech.

KEY WORDS: need of punishment, punishment, penal law, right to punish.

* Docente de la Universidad Autónoma de Colombia. Abogada, especialista en Sociología Jurídica de la Universidad Externado de Colombia, especialista en Instituciones Jurídico Penales de la Universidad Nacional de Colombia, magíster en Derecho Penal y Ciencias Criminológicas de la Universidad Externado de Colombia y Doctorando en Derecho de la Universidad de Buenos Aires. 


\section{Introducción}

El presente artículo muestra cómo el desarrollo actual del principio de necesidad de la pena se encuentra ligado al desenvolvimiento del acontecer histórico, como un desarrollo teórico íntimamente relacionado con el rechazo al exceso, abuso y uso arbitrario del ejercicio del ius puniendi, con la adopción de formas de Estado de corte liberal y de la concepción del hombre como sujeto de derechos. Desarrollo que evidencia un avance progresivo casi circular, como si la historia mostrara que la humanidad se mueve en una espiral en la que a medida que se avanza se topa con hechos y discursos similares que generan la sensación de estar en el mismo punto o por un camino ya transitado, pero que acorde con el desarrollo y movilidad propias de la sociedad cambiante obedece a circunstancias distintas y se avanza dentro de un nivel diferente.

\section{Primer giro discursivo: la determinación del delito y de la pena}

Como toda espiral tiene un punto de origen, ésta inicia con los métodos utilizados por el hombre en los pueblos primitivos para resolver sus conflictos, en los cuales la justicia poseía carácter privado, por lo que para solucionar las disputas no mediaba la intervención del Estado; los miembros del grupo administraban justicia a través de métodos como el tabú (desgracia divina), la venganza privada (mal superior que la víctima o su grupo infringían al autor y a su grupo), el destierro (expulsión del grupo), la ley del talión (ojo por ojo, diente por diente) o la compositio (pago en dinero) ${ }^{1}$. Sin embargo, la utilización de estos métodos no fue pacífica, ya que al realizar justicia por propia mano no existió identidad de respuesta frente a una misma conducta, lo que generó excesos en la exigencia de reparación pues dependió de lo que pensara, sintiera o creyera la parte afectada u ofendida; en algunos casos frente a una ofensa considerada como mínima se exigió una reparación superior o exagerada, que involucraba no sólo al ofensor sino también a su grupo; y en otros, reparación por conductas no constitutivas de ofensa. De allí que esta justicia privada se denominara "venganza" bajo la idea de forzar a sufrir dolor por un mal que se ocasionó, sin que fuera claro qué era lo "malo" ni cuánto dolor se podía aplicar al autor del mal. Esto mostró la necesidad de determinar qué está mal y cuánto dolor se puede infligir como respuesta.

El Estado, que hasta el momento estaba aislado y desinteresado de la administración de justicia, en medio de una época de relajamiento de la relación de lealtades personales y familiares con el soberano y, por ende, del control directo sobre los súbditos ${ }^{2}$, para recuperar el terreno perdido encontró en la solución de los conflictos la forma de hacer parte de la vida de sus vasallos, y con el discurso de evitar el desorden social se arrogó la función de administrar justicia. De esta manera, el primer giro discursivo en torno a la pena necesaria lo constituye la arrogación de la función de impo-

\footnotetext{
1. Sandoval Huertas, Emiro. Penología, partes general y especial. Bogotá: Ediciones Jurídicas Gustavo Ibáñez, 1996, pág. 47 y ss.Foucault, Michael. La verdad y las formas jurídicas. España: Gedisa. 2000, pág. 63 y ss.

2. Gómez Pavajeau, Carlos Arturo. Derecho penal y edad media. Bogotá: Giro editores Ltda., 2004, pág. 137 y ss.
} 


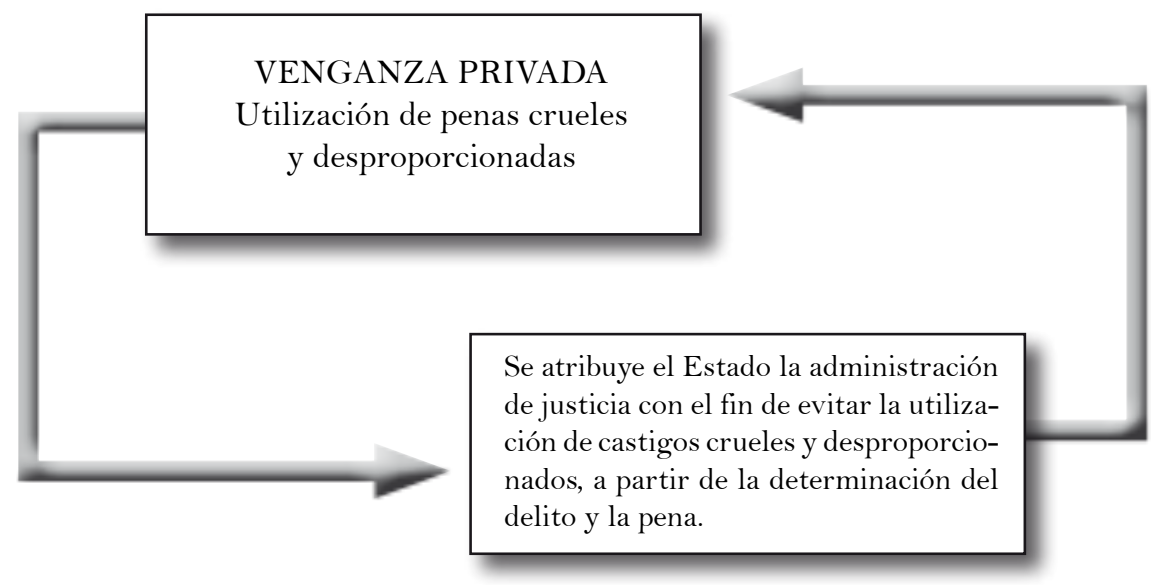

Figura 1. Primer giro discursivo en pro del control al ius puniendi.

ner castigo por parte del Estado, con el argumento de la pretendida determinación del delito y de la pena con miras a evitar el desorden social y la utilización de castigos desproporcionados.

\section{El castigo en la monarquía absoluta: ineficacia del discurso limitador del poder de castigar}

No obstante la fundamentación garantista de la sustracción del conflicto de la esfera privada, bajo el régimen de monarquía absoluta la imposición del castigo por el Estado fue utilizada como mecanismo de control, de dominación y permitió mantener la concentración del poder en el soberano $^{3}$. El soberano concentró no sólo el poder de decidir cuáles comportamientos merecían castigo y cómo debían ser castigados, sino también el de investigar y juzgar. El soberano era: el Estado, el poder legal y de justicia. Al derivar su poder de Dios, la ley del soberano se confundió con la ley divina, por tanto quien desobedecía o se rebelaba contra el soberano, desobedecía a Dios ${ }^{4}$. Además, el individuo no tenía derechos sino sólo deberes: deberes para con Dios y deberes para con el soberano ${ }^{5}$, por lo cual, existió confusión entre delito y pecado, así que las conductas perseguidas fueron aquellas consideradas como pecaminosas, heré-

3. Ibíd. Pág. 137 y ss. En igual sentido puede verse: Pavarini, Massimo. Control y dominación. México: Siglo Veintiuno Editores, 1983.

4. Córdoba Angulo, Miguel y otro. Límites al poder punitivo en la nueva Constitución y pena de muerte. En Revista derecho penal y criminología. Bogotá: Universidad Externado de Colombia, $\mathrm{N}^{\circ} 52$, pág. 37.

5. Gómez Pavajeau, Carlos Arturo. Ob. Cit. pág. 75 y ss. 
ticas, inmorales o sencillamente inconvenientes. Con la pena se pretendió restaurar la ofensa a Dios, a la propia conciencia del delincuente y a la sociedad; en todos los delitos estuvo presente la ofensa a Dios, de manera que la corrupción de la propia conciencia y la ofensa a la sociedad fueron sólo elementos cofundantes del injusto que podrían estar presentes o no, por consiguiente el sufrimiento se justificó por el premio espiritual que conlleva la limpieza del alma y la salvación eterna, es decir, un "bien mayor" futuro ${ }^{6}$.

Bien mayor que determinó la fundamentación de la pena como expiación, pues como anota Emiro Sandoval: "el autor de una conducta punible se redime a través de la sanción que recibe"7 ; la pena, entonces, adquirió un sentido espiritual donde el dolor ocasionado libera al condenado de sus culpas o pecados quedando en paz su alma, y, en reconciliación con la divinidad. Para tal redención se utilizaron penas como: la muerte, la mutilación, el tormento, la alimentación a pan y agua, el abandono noxal, el talión y la compositio ${ }^{8}$, las cuales no solo se caracterizaron por ser crueles, inhumanas, degradantes y desproporcionadas ${ }^{9}$ sino por ser todo un "espectáculo punitivo" 10 .

Así, debido a la concentración de poderes en el soberano y a la ausencia de controles, la pena necesaria que pretendió soslayar la crueldad y falta de moderación del castigo tuvo un final similar al de la utilización de la venganza privada, de la que tan solo se diferenció en que la titularidad de la acción punitiva ya no estuvo en cabeza del particular ofendido sino en el representante de la divinidad; razón por la que algunos denominaron este período como de "venganza divina o religiosa"11, identificado por un ejercicio ilimitado del ius puniendi y la utilización de penas crueles, inhumanas y desproporcionadas.

6. Ibíd. pág. 150 y ss. También puede verse: Tomás y Valiente, Francisco. El derecho penal de la monarquía absoluta. Madrid: Tecnos, 1969. Segura Ortega, Manuel. La situación del derecho penal y procesal en los siglos XVI y XVII. En Historia de los derechos fundamentales. Tomo I. Madrid: Dikinson - Universidad Carlos III de Madrid, 1998.

7. Sandoval Huertas, Emiro. Ob. Cit. pág. 59.

8. Ibíd. págs. 55 a 58 .

9. Como muestra de la crueldad de los castigos relata Montesquieu: "Un judío, acusado de haber blasfemado contra la Virgen Santísima, fue condenado a ser desollado vivo”, pág. 184. "Un Marsias soñó que degollaba a Dionisio. Este lo mandó matar diciendo que no habría soñado por la noche si no hubiera pensado en el día”, pág.180. "En el Japón, donde las leyes trastornan todas las ideas de la razón humana, la denuncia es obligatoria en los casos más comunes; no revelar un crimen es uno de los mayores crímenes. Según el relato de un viajero dos señoritas fueron encerradas hasta la muerte en un cofre erizado de puntas; la una por cierta intriga amorosa; la otra por no haberla denunciado”, pág. 185. Montesquieu. El espíritu de las leyes. Bogotá: Ediciones Universales, 2001. Casos como éstos motivaron a Montesquieu a afirmar: "el mal ha venido de la falsa idea de que es preciso vengar a la divinidad. Pero a la divinidad es menester honrarla y no vengarla. En efecto, si nos guiáramos por esta última razón, ¿cuál sería el término de los suplicios? Para que las leyes de los hombres hayan de defenderse y vengar a un ser infinito, se habría de hacerlas con arreglo a una infinidad, no según las flaquezas, la ignorancia y los caprichos de la naturaleza humana”. Ibíd. pág. 174.

10. Véase: Foucault, Michel. Vigilar y castigar. España: Siglo XXI editores, 1998. Kramer, Heinrich y Sprenger, Jacobus. Malleus Maleficarum. (El martillo de los brujos). Trad. Floreal Maza. Buenos Aires: Ediciones Orión, 1956.

11. Sandoval. Ob. Cit. págs. 61 y 59. 


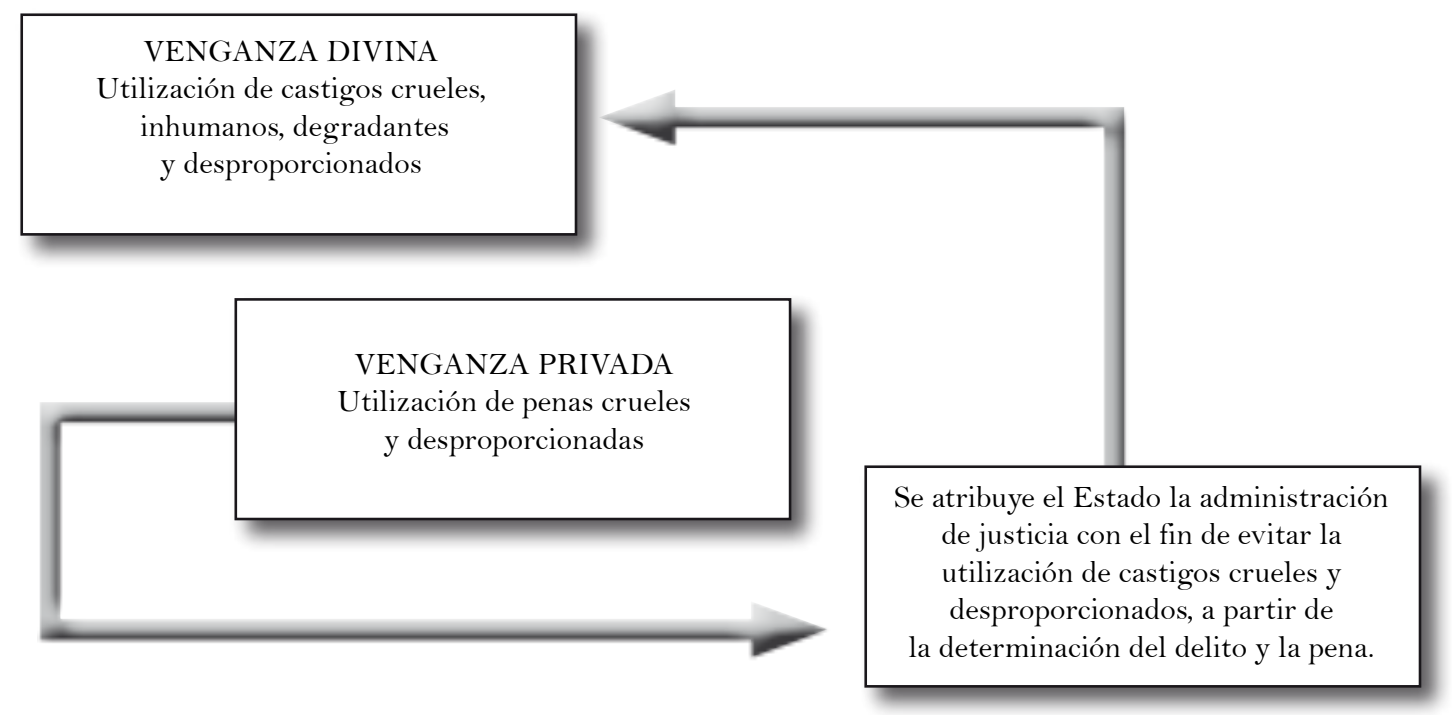

Figura 2. Ineficacia del discurso limitador del poder de castigar.

Paulatinamente, la cambiante sociedad presentó un aumento en la población, que conllevó el florecimiento de la industria y el comercio. A ello se unió la expansión colonialista hacia América, África y otros territorios, por lo que el usufructo del trabajo de los penados resultó conveniente para los nuevos intereses sociales, de forma que la fundamentación expiatoria de la pena se fue desvaneciendo a la par que cobraba fuerza como retribución para soportar la introducción de sanciones orientadas a la explotación de la mano de obra, como las galeras, los presidios, la deportación y los establecimientos correccionales ${ }^{12}$.

Bajo esta nueva fundamentación, la pena se cimentó sobre la 'necesidad moral' que tornó como necesaria la sanción que produjera al autor un mal que compensara el 'mal' causado con el delito, lo que permitió que la redención del condenado fuera obtenida a través del trabajo, cuyo lucro equivaldría al daño ocasionado con la conducta delictiva.

\section{Segundo giro discursivo: la pena necesaria como cimiento del derecho penal}

Del mercantilismo y el triunfo de la industria capitalista surgió la clase burguesa que concentró poder económico, lo que generó nuevos factores de dominio que sustituyeron la dependencia personal al soberano por la dependencia de las cosas y llevó a la revisión de la concepción de Estado, al replanteamiento del origen divino del poderío del soberano, de la concentración de poderes y funciones, de la incuestionabilidad de sus decisiones y de la inexistencia de órganos de control. Como Hazard lo expone, 
en este período a una civilización fundada sobre la idea del deber: los deberes para con Dios y los deberes para con el príncipe; los "nuevos filósofos" intentaron sustituirla por una civilización fundada en la idea del derecho: los derechos de la conciencia individual, los derechos de la crítica, los derechos de la razón, los derechos del hombre y del ciudadano ${ }^{13}$.

Para tal fin elaboraron la teoría del Contrato Social, con la que se explica el poder como proveniente de un acuerdo entre los ciudadanos que querían asegurar su libertad y convivencia pacífica frente a los ataques de terceros ${ }^{14}$. Teoría que soportó un nuevo derecho penal en el cual "el delito es el ejercicio de una libertad o un modo de ejercitar una cierta libertad a la que se había renunciado contractualmente" ${ }^{15}$, correspondiéndole al Estado su garantía.

\section{LA NECESIDAD DE PENA DESDE LA ILUSTRACIÓN}

En este marco de ideas, con la búsqueda de un nuevo modelo de Estado reconocedor de los derechos de los ciudadanos se volvió la mirada hacia el castigo como eje de control y dominación, y se abogó por la conformación de un derecho penal 'humanista' fundado en la 'necesidad' como justificación y límite de la pena. En tal sentido Montesquieu, en 1748, afirmó: "toda pena que no se derive de la necesidad es tiránica; la ley no es un mero acto de poder, y las cosas indiferentes no le incumben"16; luego Beccaria, en 1764, sostuvo:

Todo acto de autoridad de hombre a hombre, que no se derive de la absoluta necesidad, es tiránico. Veis aquí la base sobre la que el soberano tiene fundado su derecho para castigar los delitos: sobre la necesidad de defender el depósito de la salud pública de las particulares usurpaciones"(...) “Fue, pues, la necesidad quien obligó a los hombres a ceder parte de su libertad propia: y es cierto que cada uno no quiere poner en el depósito público sino la porción más pequeña que sea posible, aquella solo que baste a mover los hombres para que le defiendan. El agregado de todas estas pequeñas porciones de libertad posibles forma el derecho de castigar; todo lo demás es abuso, y no justicia: es hecho, no derecho ${ }^{17}$.

Igualmente, Rogmanosi justificó la pena en la necesidad, al afirmar:

Toda pena debe ser necesaria para que sea justa. Por lo mismo, una pena excesiva cuando más será justa sólo en la medida en que es necesaria; y más allá, será injusta ${ }^{18}(\ldots)$ la necesidad es el único punto de contacto mediante el cual el hecho de la pena puede unirse al derecho (...) la necesidad constituye el único y gran principio del cual nunca le será permitido al filósofo y al legislador separarse en lo más mínimo. Y en particular, para todo pensador que medite sobre asuntos controvertidos o defectuosamente examinados, atinentes a derecho criminal y a política, la necesidad se convierte en una de esas nociones directrices, tan celebradas y

13. Hazard, Paúl. La crisis de la conciencia europea, 1680-1715. Madrid: Ediciones Pegaso, 1975. p. XII. Citado por Nodier Agudelo en prólogo de la obra La legitimidad del derecho penal de José Joaquín Urbano MarTínEz. Bogotá: Universidad Externado de Colombia, 2001. pág. 16.

14. Córdoba Angulo, Miguel. Ob. Cit. pág. 40.

15. Pavarini, Massimo. Ob. Cit. pág. 34.

16. Montesquieu. Ob. Cit., pág. 282.

17. Beccaria, Cesare. De los delitos y de las penas. Bogotá: Universidad Externado de Colombia, 1994, pág. 11.

18. Rogmanosi, Giandomenico. Génesis del derecho penal. Bogotá: Temis, 1956, pág. 158. 
útiles, que lo guían a través de las complicadísimas y fugaces alternativas de las naciones, para divisar y escoger entre lo útil punidamente las relaciones que armonizan con lo justo. Y cuando se halle en el intrincado laberinto de las múltiples y encontradas opiniones de los numerosos tratadistas de asuntos criminales, puede decirse que la necesidad se convertirá para él en el hilo de Ariadna, con el cual podrá hacerle frente a inauditos y sanguinarios errores, mucho más puestos a la humanidad que los monstruos más feroces ${ }^{19}$.

Por otra parte, Bentham, uno de los principales exponentes del utilitarismo, mantuvo esta línea discursiva al asegurar: "La mayor utilidad, o por lo menos decir, la necesidad, es lo que justifica la pena" ${ }^{20}$.

Más adelante, en 1808, Carmignani soportó el derecho de castigar en la necesidad política, como exigencia de la índole de las pasiones humanas y de la seguridad de la agrupación o asociación política $^{21}$. Según este autor, fueron las pasiones humanas y la seguridad de la agrupación, las que produjeron la unión en sociedad y llevaron a algunos hombres, en perjuicio de los demás, a buscar gozar de mayores placeres siendo necesario juzgar dichos comportamientos como males políticos y por tanto reprimirlos como delitos ${ }^{22}$; por consiguiente, la necesidad es el origen y razón de ser del derecho penal, por lo que concluyó:

La índole de los deberes que proceden del derecho penal es la de dirigir solo las acciones externas de los hombres, pero no indistintamente, sino únicamente dentro de los límites de la necesidad política $^{23}(\ldots)$ Toda la teoría de la fijación de los delitos y de las penas se basa sobre la máxima fundamental de que la restricción de la libertad natural que de ella resulta, no debe sobrepasar los límites de la necesidad política ${ }^{24}$.

La preocupación máxima de los pensadores del iluminismo fue el establecimiento de controles al poder del Estado, dentro de los cuales se buscó limitar el poder de castigar, bajo el permiso de su utilización sólo para aquellos casos y en la medida en que fuera necesario. Sobre tal noción de necesidad cimentaron los demás pilares del derecho penal dentro de los cuales se debe resaltar la legalidad y la proporcionalidad de la pena, como complemento a la dañosidad social y el carácter personal, sin olvidar su fin, que para los iluministas radicó especialmente en la prevención de delitos ${ }^{25}$.

19. Ibíd., pág. 160 .

20. Bentham, Jeremías. Teoría de las penas y de las recompensas. Libro I. Cap. I. Paris en casa de Masson e hijo: Imprenta de E. Pochard, 1826, pág. 9.

21. Carmignani, Giovanni. Elementos de derecho criminal. Bogotá: Editorial Temis, 1979, pág. 120.

22. Ibíd., pág. 34.

23. Ibíd., pág. 17.

24. Ibíd., pág. 11.

25. Beccaria sostiene "El fin, pues, no es otro que impedir al reo causar nuevos daños a sus ciudadanos y retraer a los demás de la comisión de otros iguales. Luego deberán ser escogidas aquellas penas y aquel método de imponerlas, que guardada la proporción hagan una impresión más eficaz y más durable sobre los ánimos de los hombres, y la menos dolorosa sobre el cuerpo del reo” Op. Cit. pág. 30. En igual sentido se expresa Bentham Jeremy: "la prevención general es el fin principal de las penas; es también su razón justificativa”. Teoría de las penas y de las recompensas. pág. 4. En igual sentido, Bustos Ramírez, Juan. Introducción al derecho penal. Bogotá: Temis. 1994, pág.100. 
Luego de la lucha y el derramamiento de sangre que conllevó la revolución con la que se logró el reconocimiento de los derechos del hombre, deshacer el yugo monárquico y dar paso al Estado burgués, tales postulados justificadores de la pena se positivizaron en documentos históricos como la Declaración de Derechos del Buen Pueblo de Virginia (junio 12 de 1776) en su Art. 9: "No se exigirán fianzas excesivas ni se impondrán multas excesivas ni se infligirán castigos crueles o inusitados" y la Declaración Francesa de los Derechos del Hombre y del Ciudadano (1789), Art. 8: "La ley no debe establecer otras penas que las estricta y evidentemente necesarias, y nadie puede ser castigado sino en virtud de una ley establecida y promulgada con anterioridad al delito, y legalmente aplicada" ${ }^{26}$. De esta forma, el Estado de Derecho, caracterizado por el reconocimiento de derechos y libertades fundamentales, el imperio de la ley como expresión de la voluntad general, la división de poderes públicos y la necesidad como soporte del derecho penal y de la pena, inició la tendencia hacia el desarraigo de las funciones vindicativa, expiacionista y retributiva de la pena.

A pesar de que los pensadores del iluminismo abogaron por la existencia de una gran variedad de alternativas sancionadoras, acordes con la diversidad de conductas punibles y se opusieron a las penas privativas de la libertad, éstas se fueron entronizando como pena principal ${ }^{27}$, dentro de las cuales la institución con mayor relevancia fue la cárcel, cuya creación se justificó bajo el argumento de que con ella la pena se torna incruenta e igualitaria, legalmente predeterminada, susceptible de medición y cálculo por considerar que se trata de

la privación de un tiempo abstracto de libertad, exactamente cuantificable y graduable por la legislación y luego por el juez, en relación con la gravedad -en abstracto y en concreto- de los delitos castigados ${ }^{28}$.

Argumento que trató de soterrar el que la privación de libertad se acogiera como castigo al considerarla como un valor económico ${ }^{29}$ que al ser privado ocasiona un mal, un sufrimiento, un dolor, pues dentro de la ideología burguesa "la libertad medida en el tiempo constituye de hecho la forma más simple del valor de cambio"30 y permite ejercitar sobre el condenado un 'poder disciplinar' consistente en educarlo conforme a las necesidades del proceso productivo para reintegrarlo a la vida en sociedad con un comportamiento acorde con el Pacto Social ${ }^{31}$.

\footnotetext{
26. Ferrajoli, Luigi. Derecho y Razón. Madrid: Editorial Trotta, 1996, pág. 92.

27. En este sentido resulta interesante el análisis que realiza Emiro Sandoval, al cual remitimos. Ob. Cit. págs. 82 a 89.

28. Ferrajoli, Luigi. La pena en una sociedad democrática. En La pena garantismo y democracia. Bogotá: Ediciones Jurídicas Gustavo Ibáñez, 1999, pág. 24.

29. Pavarini desarrolla esta idea de la siguiente manera: "Sólo con la aparición del nuevo sistema de producción la libertad adquirió un valor económico: en efecto, sólo cuando todas las formas de la riqueza social fueron reconocidas al común denominador de trabajo humano medido en el tiempo, o sea de trabajo asalariado, fue concebible una pena que privase al culpable de un quantum de libertad, es decir, de un quantum de trabajo asalariado. Y desde este preciso momento la pena privativa de la libertad, o sea la cárcel, se convierte en la sanción penal más difundida, la pena por excelencia en la sociedad productora de mercancías”. PAVARINI, Massimo. Ob. Cit., pág. 36.
}

30. Ibíd., pág. 37.

31. Ibíd., pág. 37 
Privación de la libertad que se fundamentó en la finalidad correccional y resocializante de la pena. En la fase correccionista de finales del s. XIX hasta las primeras décadas del s. XX, el Estado como titular único de la potestad punitiva utilizó como método sancionatorio el régimen penitenciario, con la aspiración de corregir o enmendar a quien vulnerara un determinado ordenamiento. Se introdujo entonces el concepto de tratamiento, y el comportamiento futuro fundamentó la imposición y ejecución de la pena, por tanto, sus fines fueron, en primer lugar, de corrección al condenado y, segundo, de intimidación a la colectividad. Así mismo, en la fase resocializante, ubicada en las tres últimas décadas del siglo XIX, el ejecutor de la pena se limitó a 'tratar' al sentenciado, utilizando como método el tratamiento penitenciario. Las instituciones características de esta fase fueron: el régimen progresivo, el régimen all aperto y la prisión abierta ${ }^{32}$.

Así, el cambio de modelo de Estado marcó otro giro discursivo en el cual, al ser considerado el hombre como sujeto de derechos, se buscó limitar el ejercicio del poder punitivo del Estado y se abogó por la utilización de penas necesarias, incruentas, proporcionales y predeterminadas en la ley.

\section{Tercer giro discursivo: el hombre sujeto de} deberes y el abandono de la pena necesaria

No obstante, tal esfuerzo en procura de la humanización del derecho penal y las garantías del procesado, fruto de la revolución y la lucha en contra de

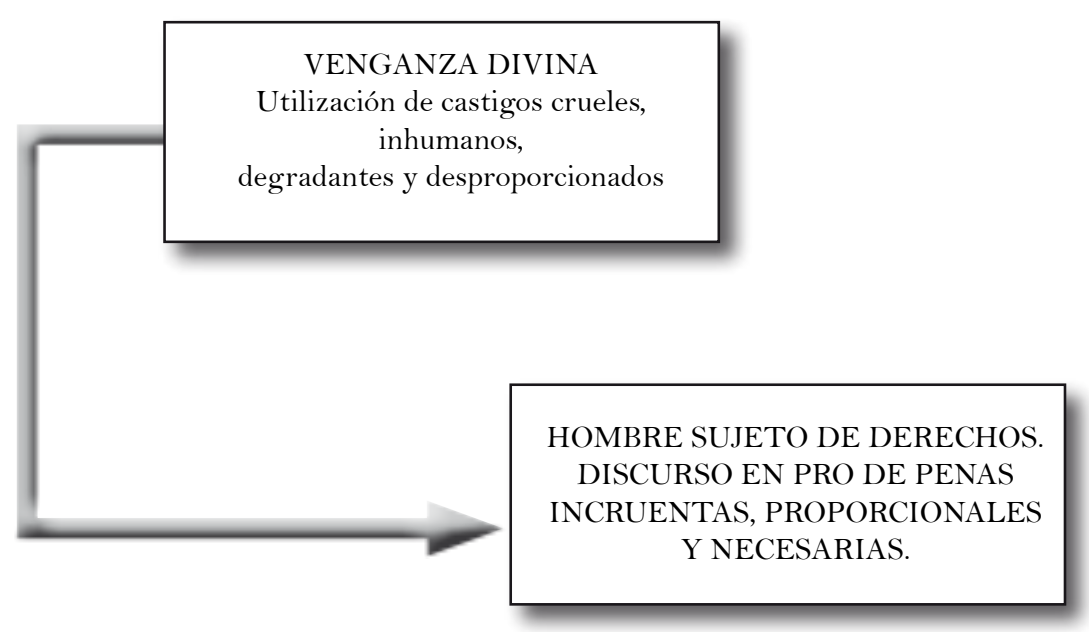

Figura 3. Segundo giro discursivo. El reconocimiento de los derechos del hombre y el establecimiento de límites al ius puniendi y penas necesarias. 
la tiranía monárquica, se fue desvaneciendo como resultado de la implantación de regímenes dictatoriales y autocráticos en los que "se alude al Estado de Derecho como una institución destinada a ser "superada" y valorada negativamente",33, a la vez que se proclamó la supremacía del Estado sobre el ciudadano, se impuso la ideología única del partido a través de la violencia y el terror como sistema de control, mientras que los derechos humanos, libertades y garantías fundamentales se vieron limitados y reducidos a su mínima expresión ${ }^{34}$.

Fue así como entró en crisis el movimiento que se desarrolló a lo largo del siglo XIX hasta la Primera Guerra Mundial, conocido como 'constitucionalismo liberal', según el cual los Estados debían regirse por constituciones de carácter democrático-liberal, cuyos ideales resume Naranjo Mesa de la siguiente manera:

“a) Dotar a los Estados de una Constitución, como ley fundamental a la cual estén sometidos gobernantes y gobernados. b) Distribuir en ramas separadas las funciones legislativa, ejecutiva y jurisdiccional, desconcentrando así el ejercicio del poder público y evitando que sea absorbido por una sola rama: la ejecutiva. c) Consagrar y garantizar, a través de la Constitución, los derechos individuales y las libertades públicas frente al Estado. d) Otorgarle al pueblo la titularidad exclusiva de la soberanía. e) Establecer limitaciones y controles al poder de los gobernantes" $"$.

Crisis que se reflejó en el derecho penal, en el que acorde con la concepción del hombre como sujeto de deberes se tomaron medidas como: abolir el principio de legalidad, aplicar la ley penal retroactivamente y por analogía, y el sometimiento de los jueces a los dictados del ejecutivo y no a la norma ${ }^{36}$. Derecho penal cuyo fundamento fue establecido por el deber de fidelidad del pueblo, al instituir un derecho penal de intención en el que la antijuridicidad adquirió un carácter subjetivo al entenderse el delito como la violación de un deber, penando por tanto la voluntad del agente y no el acto $^{37}$.

Derecho penal en el que la necesidad de pena como control al poder punitivo desapareció, al quedar al arbitrio del dictador determinar qué y cómo castigar, debido a que, como sostiene Zaffaroni, en el marco de un derecho penal de autor y de un régimen desconocedor de los derechos y libertades del ciudadano, la pena, siempre que así se quiera, será necesaria con fines preventivos, acorde con la intangibilidad de la dañosidad social, como la carencia de proporcionalidad y subsidiariedad ${ }^{38}$. Carencia de la pena necesaria que llevó a los ho-

33. Cattaneo, Mario A. Carl Schmitt y Roland Freisler: la doctrina penal del nacional-socialismo. En: http://www.uclm.es/aidp/pdf/ barbero 1/8.pdf. Disponible a 30 de diciembre de 2007.

34. Córdoba Angulo, Miguel. Ob.Cit. pág. 41.

35. Naranjo. Op. Cit., pág. 33.

36. Sobre este tema puede verse RafEcas, Daniel. "El derecho penal frente al holocausto (a propósito de unas obras recientes de Francisco Muñoz Conde y de Enzo Traverso)”. En: http://www.catedrahendler.org/material_in.php?id=6\&PHPSESSID=1f923ff7 1 b 3d1f7a4b141657818022d 1 y Velásquez Velásquez, Fernando. Manual de derecho penal. Bogotá: Temis, 2002 , pág. 183.

37. Gómez Pavajeau, Carlos Arturo. Estudios de Dogmática en el nuevo código penal. Segunda parte. Bogotá: Ediciones Gustavo Ibáñez, 2004, págs. 68 y 70 .

38. Zaffaroni, Eugenio. El enemigo en el derecho penal. Buenos Aires: Ediar, 2006, pág. 26. 


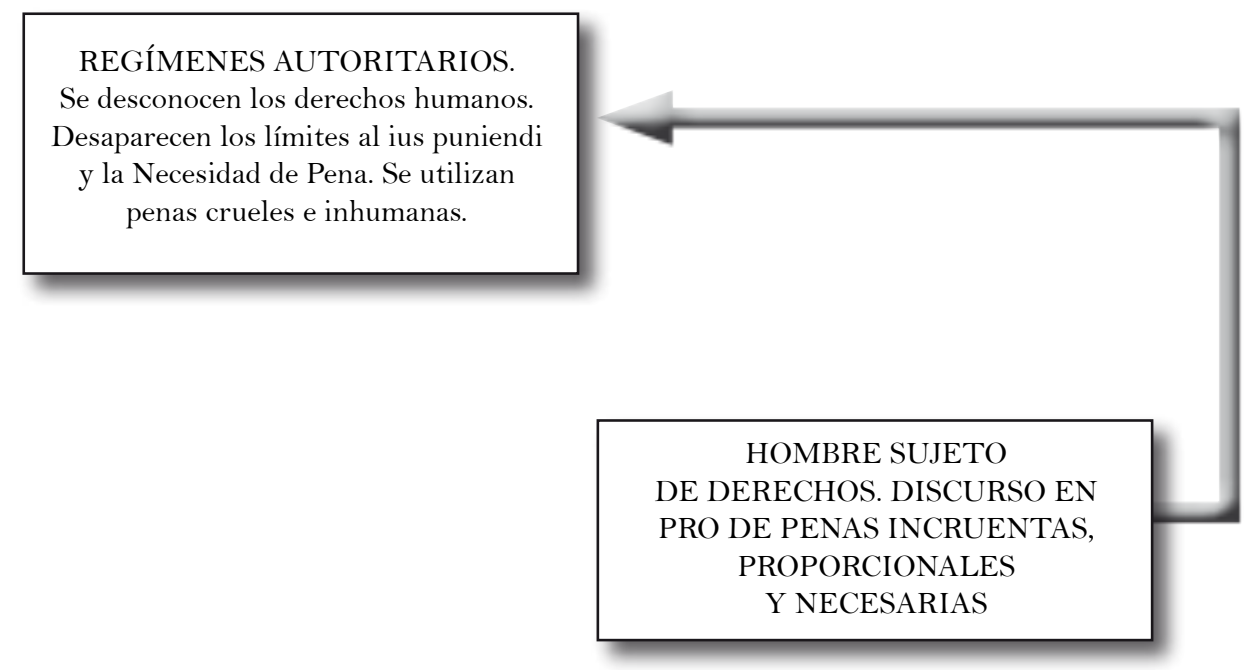

Figura 4. Desconocimiento de los derechos del hombre y utilización de penas arbitrarias.

rrores que narra la historia, dentro de los cuales cabe recordar cómo se empleó el hambre y el trabajo como estrategias de exterminio, el uso de los asesinatos arbitrarios con el fin de mantener la disciplina de los reclusos, las cámaras de gas, los experimentos médicos con los presos con el fin de lograr la esterilización en masa, la investigación de gemelos y la experimentación de medicamentos ${ }^{39}$.

\section{Cuarto giro discursivo: el hombre sujeto de derechos y la pena necesaria}

En respuesta a los regímenes de horror, una vez más se volvió la mirada al constitucionalismo liberal y a los derechos del hombre como medida de contención del poder del Estado. Como afirma De Vergottini:

Los principios del constitucionalismo liberal se confirman al término de la Segunda Guerra Mundial en Europa occidental y consolidan una posición de influencia en otros continentes. En la práctica, todas las áreas interesadas por estar en la esfera de acción de las potencias aliadas diferentes de la Unión Soviética se ven condicionadas por el modelo constitucional compartido por los vencedores e inspirado en los principios del liberalismo político. En algunos casos se trata de la continuación de un natural proceso de desarrollo político constitucional que sigue al paréntesis del Estado autoritario (Italia) y al peligro de la guerra y de la ocupación extranjera (Francia, Bélgica, Holanda, Luxemburgo, Dinamarca, Noruega, Finlandia, Austria, Grecia). En otros, se presenta la ya recordada imposición por parte de las potencias ocupan-

39. "Auschwitz. Objetivo final: el exterminio. Los métodos de exterminio” En: http://www.wsg-hist.uni-linz.ac.at/auschwitz/htmlesp/ Entwicklung.html 
tes de un modelo político constitucional en línea con el de los vencedores (Alemania, Japón). ${ }^{40}$

Este retorno al reconocimiento de los derechos del hombre no tuvo influencia exclusivamente en Europa; instrumentos como la Carta de la Organización de las Naciones Unidas, de 1946 y la Declaración Universal de los Derechos Humanos de 1948, encontraron eco en la creación del sistema americano de derechos humanos en el que sobresalen el Pacto Internacional de Derechos Económicos, Sociales y Culturales, y, el Pacto Internacional de Derechos Civiles y Políticos, de 1966; los cuales poco a poco fueron adoptados por los Estados en sus constituciones, quedando así sentados los derechos y garantías mínimas que posee el ser humano como límites constitucionales al ius puniendi.

\section{La necesidad de pena desde la posguerra}

El paso al Estado Social de Derecho, implicó un poder punitivo con límites establecidos a partir del reconocimiento de la dignidad humana y de los derechos del hombre. En este marco, en los años 70 una vez demostrados los peligros del positivismo y de los excesos a los que se puede llegar bajo la utilización incontrolada del ius puniendi, reapareció con fuerza el discurso de la necesidad de pena como límite, esta vez, a través de la discusión de la dogmática penal, por su introducción dentro del esquema del delito como barrera efectiva al poder de castigar, bien como: sustituto de la culpabilidad, parte de una tercera categoría dogmática denominada responsabilidad, cuarta categoría, o principio rector del ordenamiento penal.

LA NECESIDAD DE PENA COMO SUSTITUTO DE LA CULPABILIDAD. Frente al descrédito de la categoría dogmática de la culpabilidad, por tener como fundamento el indemostrable libre albedrío, se propuso sustituirla por la necesidad preventiva de pena, por considerar que se justifica por su necesidad y su idoneidad para lograr una vida social, siendo por tanto reprochable causar más padecimiento del absolutamente indispensable. De esta forma, la pena no retribuye una culpabilidad inexistente e indemostrable sino que refuerza las prohibiciones cuya observancia es necesaria para evitar la práctica de conductas que atacan las bases de la convivencia social. En este orden de ideas el esquema del delito quedaría estructurado como lo muestra la figura 5 .

\section{Conducta: Típica + Antijurídica + Necesitada de pena $=$ Pena}

Figura 5. Esquema del delito. La necesidad de pena como sustituto de la culpabilidad.

40. De Vergottini, Giuseppe. Las transiciones constitucionales. Bogotá: Universidad Externado de Colombia, 2002 , pág. 71. 
LA NECESIDAD DE PENA COMO PARTE DE LA RESPONSABILIDAD. Otra posición es la sostenida por Roxin, quien afirma que no se debe suprimir la culpabilidad por cuanto cumple la función de servir de límite a la pena, por lo cual aunque su fundamento sea indemostrable pierde relevancia al ser beneficioso para el delincuente, al impedir que por razones preventivas se limite su libertad por encima del grado de su culpabilidad; aclarando que la culpabilidad es un medio de limitar la pena pero no de fundamentarla, por tratarse de una condición necesaria pero no suficiente ${ }^{41}$, debido a que el reproche de culpabilidad se fundamenta en los principios de política criminal de la teoría de la pena, a la luz de los cuales debe analizarse la necesidad de pena ${ }^{42}$. Este último análisis es el que permitirá establecer como resultado la responsabilidad penal del sujeto, es decir, que en el juicio de reproche que se hace al sujeto, en caso de que éste no pueda actuar de otro modo, quedan excluidas la culpabilidad y la punibilidad, pero si el sujeto podía actuar de otro modo, con tal comprobación no se decide su punibilidad y debe indagarse si es necesario el castigo.

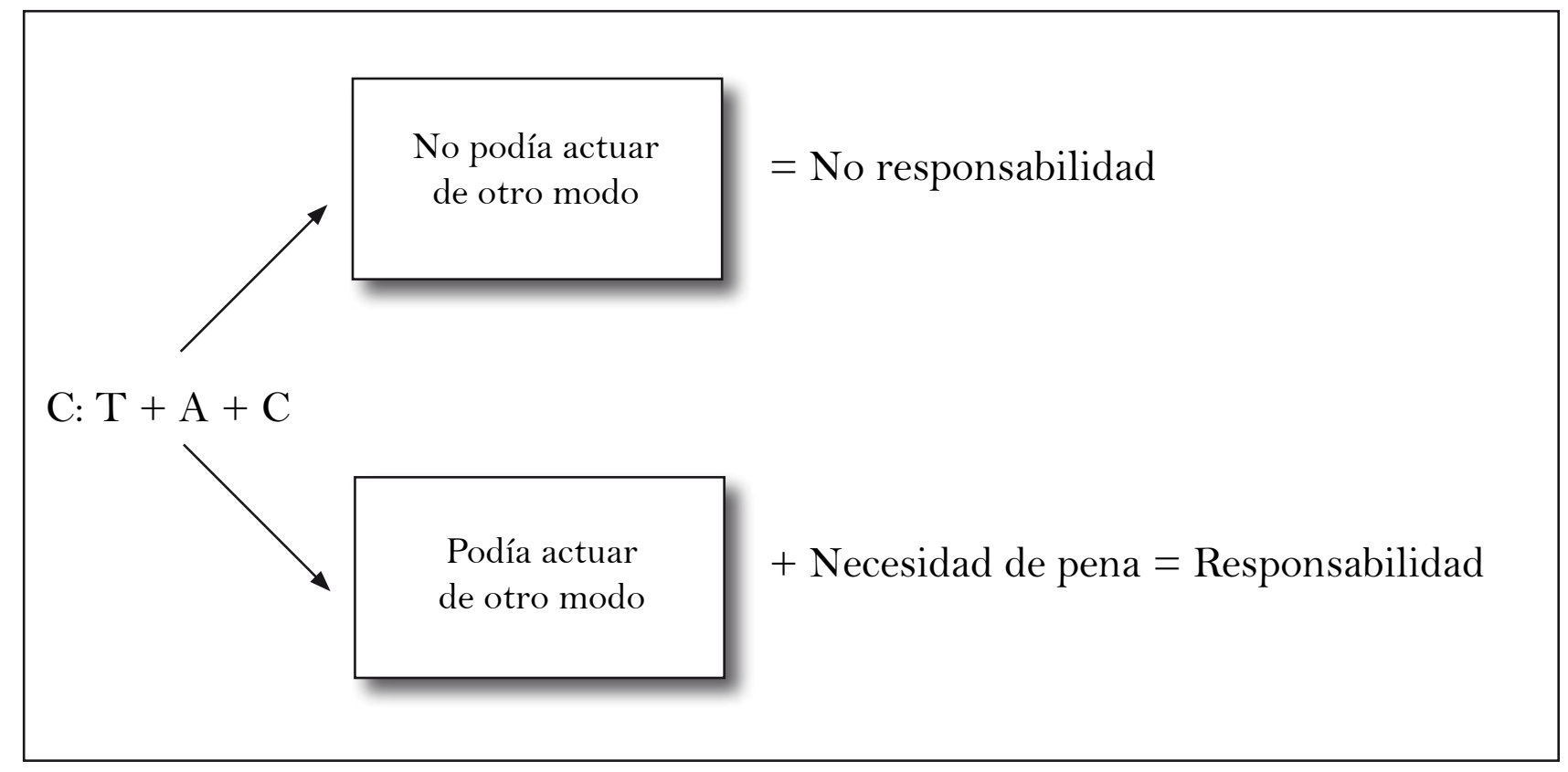

Figura 6. Esquema del delito. La responsabilidad como tercera categoría del delito.

41. Roxin, Claus. Culpabilidad y prevención en derecho penal. España: Reus S.A., 1981, págs. 46 y ss.

42. En el tratado Roxin la denomina "necesidad preventiva” de la sanción penal. Roxin, Claus. Derecho Penal. Parte general. Madrid: Civitas, 1997, pág. 791 y ss. 


\section{Conducta: Típica + Antijurídica + Responsable $=$ Pena}

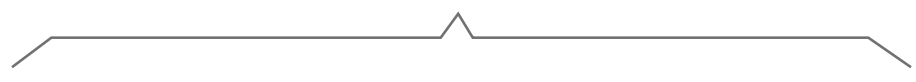

\section{Culpable + Necesitada de pena}

Figura 7. Esquema del delito. La necesidad de pena como parte de la responsabilidad.

Conforme a lo anterior, el esquema del delito propuesto por este autor se podría graficar como aparece en la figura 7 .

LA NECESIDAD DE PENA COMO CUARTA CATEgoría DOGMÁTiCA. Por otra parte, en consonancia con la propuesta de Roxin, otro sector de la doctrina abogó por la necesidad de pena como cuarta categoría dogmática. Tal es el caso de Córdoba Roda (1977), quien sostiene que de suprimirse la culpabilidad no se ofrece una determinación en materias como la inimputabilidad y el error de prohibición ${ }^{43}$. La inimputabilidad, por considerar que en caso de trastorno mental transitorio aunque el Código Penal Español no supone aplicación de medida alguna, con base en la prevención se podría necesitar la pena: primero, por razones de prevención general, pues al no ser apreciado el trastorno por cualquier persona, para la sociedad puede parecer un subterfugio para evitar la condena; segundo, por razones de prevención especial, porque el trastorno mental transitorio ofrece por su base patológica un riesgo de comisión en el futuro de nuevos hechos delictivos, por lo cual se debe aplicar una sanción capaz de evitar la peligrosidad del sujeto. Frente al error de prohibición, que cuenta con exención de responsabilidad penal, podría ocurrir que por razones de prevención especial el autor necesite pena, pues, no obsta para que pueda manifestar características de gravísima peligrosidad criminal; además, porque las categorías de evitable e inevitable del error representan gran dificultad, debido a que exigen conocimiento de la contrariedad a derecho y conocimiento del precepto penal incriminador de la acción, y frente a tal evento únicamente los juristas estarían en situación de delinquir.

Adicionalmente, Córdoba sostiene que sustituir la culpabilidad por la necesidad preventiva de la pena implica un riesgo para ciertas garantías a favor de la persona humana, puesto que, en primer lugar, en virtud de la prevención general es posible proponer la aplicación de penas desproporcionadas a la gravedad del acto, si resulta necesario para prevenir la comisión de hechos

43. Córdoba Roda, Juan. Culpabilidad y pena. España: Bosch, Casa Editorial, 1977, pág. 26. 
causantes de elevada alarma o inquietud para la comunidad estatal; y en segundo lugar, en virtud de la prevención especial, si la acción manifiesta una considerable peligrosidad, es posible imponer una sanción de una intensidad adecuada a ésta, aun cuando la gravedad de la conducta realizada sea ínfima ${ }^{44}$.

Acorde con esta postura el esquema del delito se podría graficar así:

\section{Conducta: Típica + Antijurídica + Culpable + Necesitada de pena $=$ Pena}

Figura 8. Esquema del delito. La necesidad de pena como cuarta categoría dogmática.

LA NECESIDAD DE PENA COMO PRINCIPIO. Finalmente, se encuentra la postura que sostiene que la necesidad de pena es un principio material que opera tanto en la fundamentación como en la limitación y la exclusión de todos los elementos del delito, al igual que en la de otros requisitos de la pena no referidos al hecho, sin conformar una categoría sistemática autónoma ${ }^{45}$.

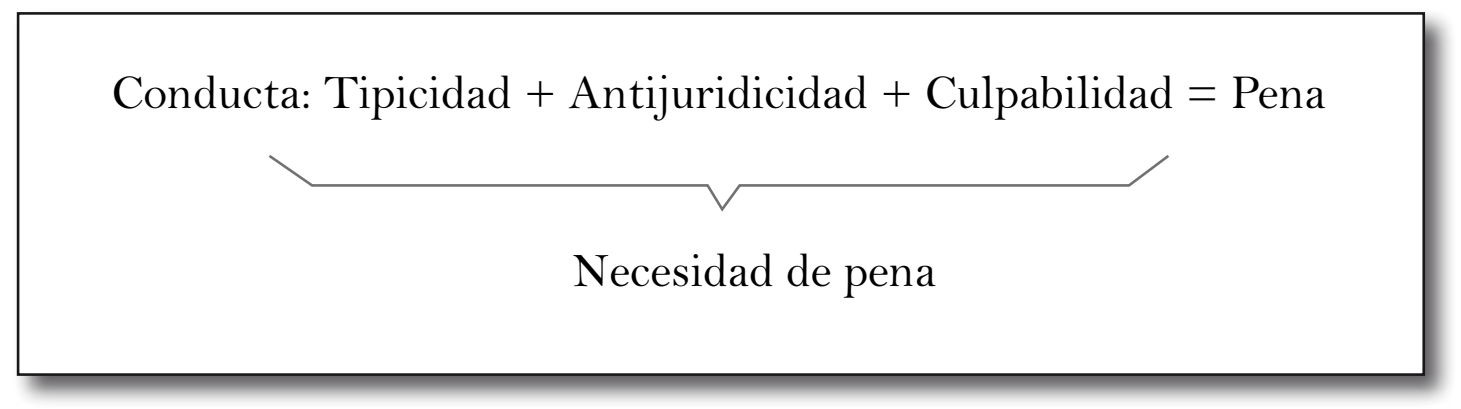

Figura 9. Esquema del delito. La necesidad de pena como principio.

44. Córdoba Roda, Juan. Ob. Cit., pág. 42.

45. En tal sentido ver Luzón PeÑa, Diego Manuel. La relación del merecimiento de pena y de la necesidad de pena con la estructura del delito. En Fundamentos de un sistema europeo del derecho penal. Libro homenaje a Claus Roxin. Barcelona: J.M. Bosch Editor S.A., págs. $115 \mathrm{y} \mathrm{ss.}$ 
Postura que en gran medida tiene como funda- los que se deducen los principios orientadores de mento el "sistema garantista del derecho penal" la forma como se debe castigar, prohibir y juzgar de Ferrajoli, conformado por los 10 axiomas de (tabla1).

\begin{tabular}{|c|c|c|}
\hline $\begin{array}{l}\text { PREGUNTAS QUE } \\
\text { RESPONDE }\end{array}$ & $\begin{array}{c}\text { AXIOMAS DEL SISTEMA } \\
\text { GARANTISTA }\end{array}$ & PRINCIPIOS \\
\hline \multirow[t]{3}{*}{ ¿Cuándo y cómo castigar? } & A 1. Nulla poena sine crimine. & 1. Principio de retributividad. \\
\hline & A 2. Nullum crimen sine lege. & 2. Principio de legalidad. \\
\hline & $\begin{array}{l}\text { A 3. Nulla lex (poenalis) sine } \\
\text { necessitate. }\end{array}$ & $\begin{array}{l}\text { 3. Principio de necesidad o de } \\
\text { economía del derecho penal. }\end{array}$ \\
\hline \multirow{3}{*}{ ¿Cuándo y cómo prohibir? } & $\begin{array}{l}\text { A 4. Nulla necesitas sine iniu- } \\
\text { ria. }\end{array}$ & 4. Principio de lesividad. \\
\hline & $\begin{array}{l}\text { A } 5 . \text { Nulla iniuria sine actio- } \\
\text { ne. }\end{array}$ & $\begin{array}{l}\text { 5. Principio de materialidad o de } \\
\text { exterioridad de la acción. }\end{array}$ \\
\hline & A 6. Nulla actio sine culpa. & $\begin{array}{l}\text { 6. Principio de culpabilidad o de } \\
\text { la responsabilidad personal. }\end{array}$ \\
\hline \multirow{4}{*}{ ¿Cuándo y cómo juzgar? } & A 7. Nulla culpa sine iudicio. & $\begin{array}{l}\text { 7. Principio de jurisdiccionali- } \\
\text { dad. }\end{array}$ \\
\hline & $\begin{array}{l}\text { A 8. Nullum iudicium sine ac- } \\
\text { cusatione. }\end{array}$ & $\begin{array}{l}\text { 8. Principio acusatorio o de la } \\
\text { separación entre juez y acu- } \\
\text { sación. }\end{array}$ \\
\hline & $\begin{array}{l}\text { A } 9 . \quad \text { Nulla accusatio sine pro- } \\
\text { batione. }\end{array}$ & $\begin{array}{l}\text { 9. Principio de la carga de la } \\
\text { prueba. }\end{array}$ \\
\hline & $\begin{array}{l}\text { A 10. } \begin{array}{l}\text { Nulla probatio sine defen- } \\
\text { sione. }\end{array}\end{array}$ & $\begin{array}{l}\text { 10. Principio del contradictorio, } \\
\text { o de la defensa. }\end{array}$ \\
\hline
\end{tabular}

Tabla 1. Axiomas del sistema garantista de Luigi Ferrajoli. 
Dentro de esta construcción axiológica, a través de la implicación o conjunción entre los teoremas correspondientes a los axiomas 1 (no hay pena sin crimen) y 3 (no hay ley penal sin necesidad $)^{46}$, demuestra la procedencia lógica de la necesidad de pena como principio del derecho penal ${ }^{47}$.

Con este nuevo clamor por el control al poder punitivo y el respeto a los derechos humanos, no sólo a través de su positivización a nivel internacional sino de la búsqueda de su consagración expresa como categoría dogmática del delito, al inquirir que al momento de la imposición de la pena la autoridad judicial deba realizar un análisis de su necesidad y, en tal forma, obligar al operador jurídico a justificar en cada caso particular su imposición, se configura el tercer giro discursivo en pro de los límites al ius puniendi y dentro de ellos de la necesidad de pena.

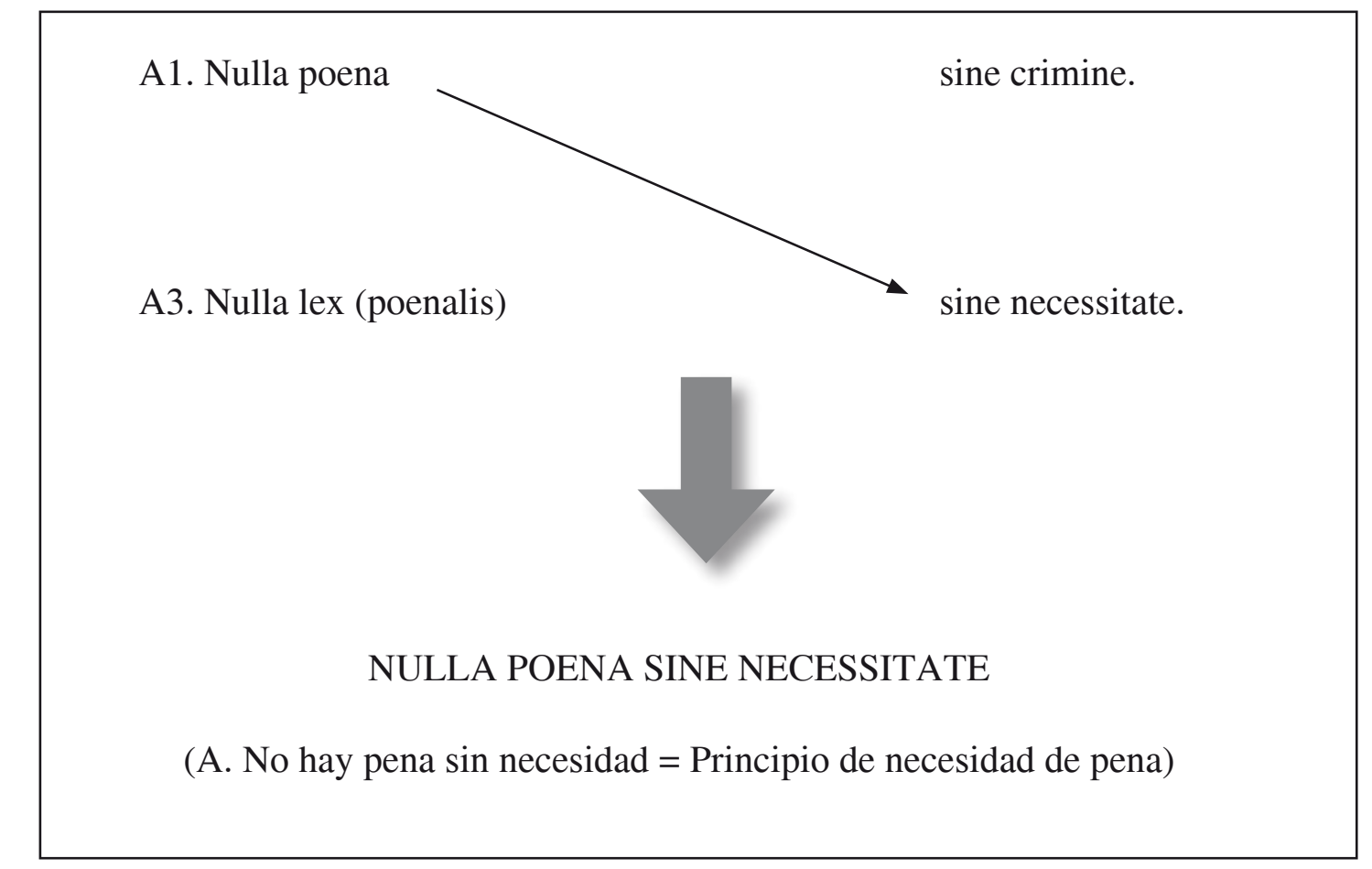

Figura 10. Principio de necesidad de pena. 


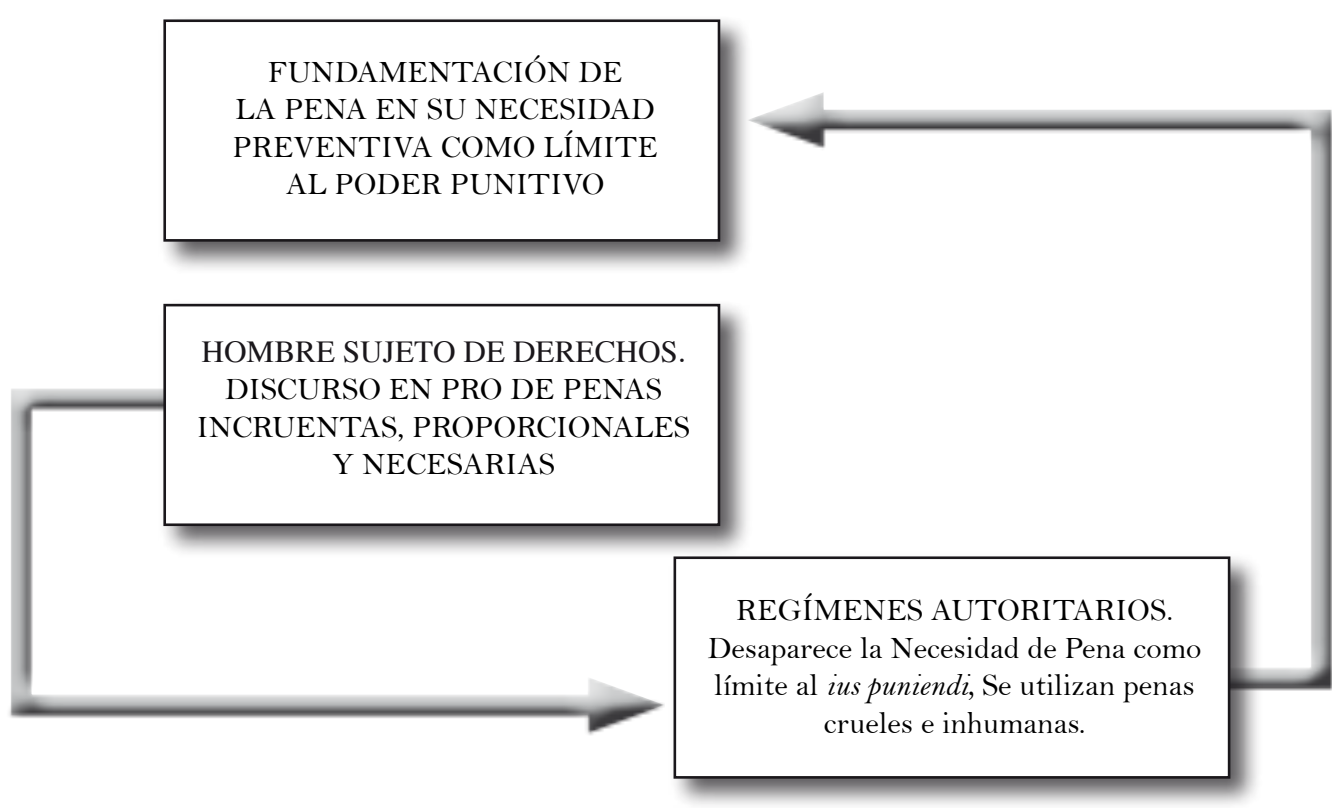

Figura 11. Cuarto giro discursivo: el hombre sujeto de derechos y la pena necesaria como límite al ejercicio del ius puniendi.

\section{El castigo al "enemigo"}

Después de este giro discursivo en favor de la humanización y los límites del derecho de castigar, acontecimientos como la caída del muro de Berlín, el postindustrialismo, el postfordismo, el capitalismo global y el neoliberalismo generaron cambios en los bienes a proteger por el derecho penal y en las modalidades delictivas, cobrando gran interés los delitos económicos, la delincuencia de cuello blanco, la protección del medio ambiente, bienes difusos y colectivos, la delincuencia organizada y el delito trasnacional ${ }^{48}$; pero ante todo, fenómenos como el narcotráfico que conlleva problemáticas como las prácticas genocidas, el desplazamiento forzado y la denominada industria del secuestro extorsivo, al igual que el terrorismo (especialmente a partir de hechos como los del 11 de septiembre de 2001 en Estados Unidos y el 11 de marzo de 2004 en España), han traido consigo una sensación de inseguridad frente a la cual se clama respuesta y control. En atención a este clamor, los Estados han adoptado medidas desconocedoras de los derechos del hombre con la utilización de prácticas violatorias de garantías procesales y judiciales como la legalidad, el derecho de defensa, el debido proceso y la prueba lícita, a la vez que se ha vuelto a introducir la tortura y el castigo cruel $^{49}$. Todo esto, inicialmente, bajo "legislaciones de excepción” y luego de "estatutos antiterroristas".

48. Silva Sánchez, Jesús María. La expansión del derecho penal. Argentina: Editorial B de F., 2006, págs. 11 y ss. 49. Para ampliar al respecto puede verse: www.amnesty.org/es/counter-terror-with-justice 


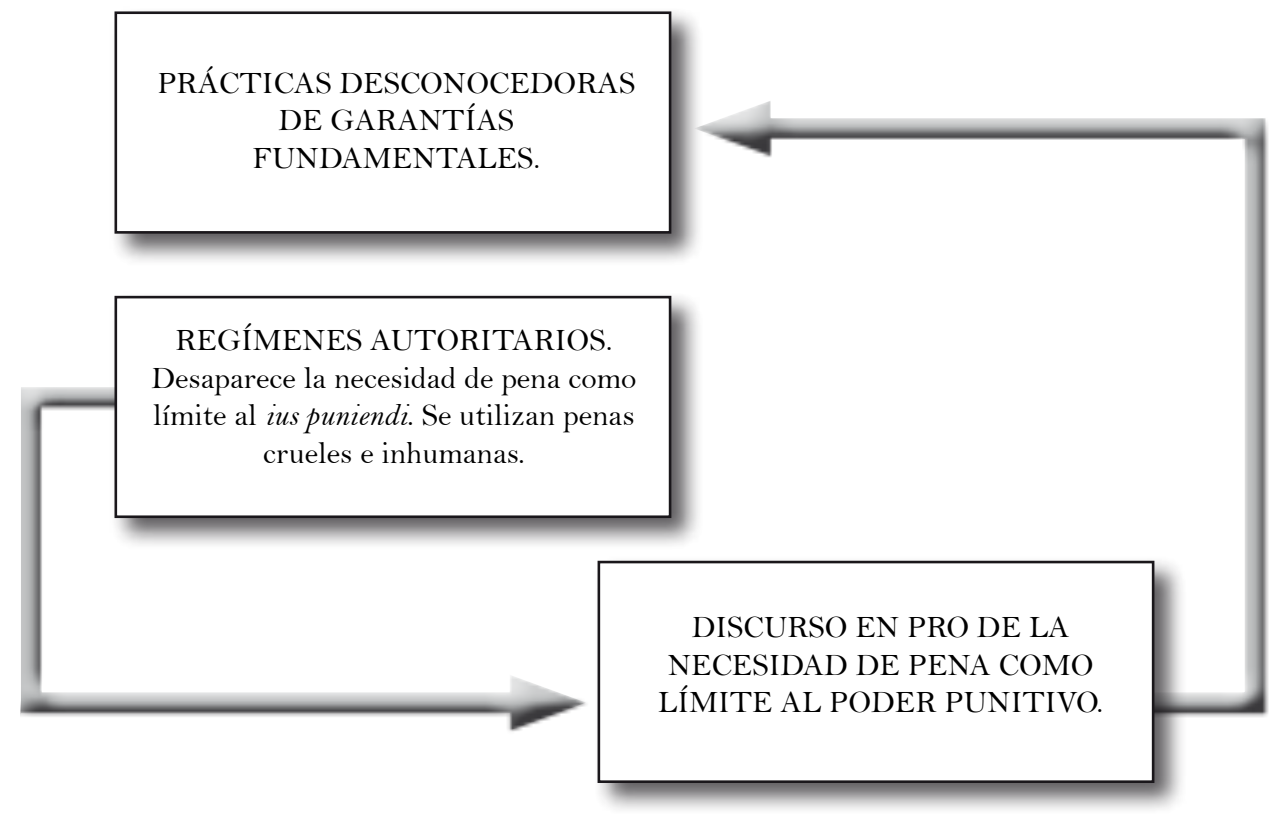

Figura 12. Prácticas desconocedoras de los derechos y garantías del hombre.

Tales legislaciones han generado un doble discurso: por una parte, los Estados reconocen los derechos fundamentales del hombre y suscriben acuerdos internacionales sobre los mínimos que en materia de garantías se obligan a respetar, participan en organizaciones internacionales promotoras de derechos humanos, que elaboran políticas criminales orientadas a garantizar esos derechos (como ocurre con el trabajo que desarrolla el Instituto Latinoamericano de las Naciones Unidas para la Prevención del Delito y Tratamiento del Delincuente -ILANUD), y a la par, bajo el discurso de garantizar la seguridad de sus nacionales, con legislaciones de emergencia o antiterroristas los desconocen. Esta situación generó la necesidad de un discurso que racionalice tal incoherencia y justifique la mengua de las garantías ciudadanas, dotándola de un ropaje de "juridicidad” que garantice su impunidad, finalidad de suyo imposible si el debate se realiza a la luz del Derecho Internacional Humanitario y del Derecho Internacional de los Derechos Humanos, los cuales se pretenden evadir. Así que, la mejor forma de dotar las prácticas desconocedoras de los derechos humanos de un supuesto "ropaje de juridicidad" ha sido elaborar un discurso legitimante por fuera de ese ámbito, lo que reduce el marco de opciones a la legislación interna. Dentro del derecho interno, los doctos en materia constitucional impiden su justificación por implicar un desconocimiento a la "Constitución dogmática”, por lo que nuevamente confluyó en los teóricos del derecho penal la realización de tal tarea, encontrando teorías como las del "derecho penal de dos velocidades" o la del "derecho penal del enemigo", con las que se diferencian dos formas de criminalidad: la de la "criminalidad tradicional" y la de "los nuevos fenómenos criminales", con la premisa de que para los primeros existe un sistema garantista, y para los segundos, uno más flexible.

Así, el "derecho penal” se ha pretendido fraccionar en dos. Por un lado, un derecho penal garantista, dirigido a sancionar la conducta o el acto del in- 
dividuo, entendido éste como sujeto de derechos. Cuestiona la tendencia expansionista del derecho penal, aboga por un derecho penal mínimo y por la eficacia del control al ius puniendi; un derecho penal en el que la discusión respecto a la pena se centra en lo referente a su legitimidad, en atención a las diversas críticas que se han hecho a su justificación, como por ejemplo: a) la retribución requiere el libre arrepentimiento del culpable, pues se produce en el interior de la persona y depende de su disposición psíquica, de tal forma que si el autor no tiene sentimiento de culpabilidad la pena no cumple su función ${ }^{50}$; b) la idea de retribución compensadora sólo se puede hacer plausible mediante un acto de fe pues no se puede comprender racionalmente cómo se puede borrar un mal cometido al añadir un segundo mal, como es el sufrimiento de la pena ${ }^{51}$; c) el aplicar la pena para intimidar a los demás se constituye en una violación a la ley ética de Kant de no instrumentalizar al ser humano; d) no se ha podido probar el efecto intimidatorio de la pena, siendo cada delito comprobación de su fracaso ${ }^{52}$; e) si la pena se aplica para resocializar al criminal se muestra al criminal como algo socialmente deseable, pues si se quiere una sociedad ajustada se debe criminalizar y penar a todos, porque la pena es el medio a través del cual se logra la aceptación de los valores dominantes; f) la resocialización no posibilita la delimitación temporal de la pena pues al perseguirse un tratamiento hasta darse la corrección su duración puede ser indefinida ${ }^{53}$. Igualmente, respecto a las teorías de la unión, que tratan de combinar los anteriores fundamentos al justificar la pena en su capacidad para reprimir y prevenir al mismo tiempo, se cuestiona que tratan de dar armonía a algo que es excluyente ${ }^{54} \mathrm{y}$, por tanto, las actuales legislaciones que las adoptan generan en sus operadores jurídicos dificultades en su práctica por la falta de criterios unánimes de aplicación de las distintas finalidades de la pena en virtud de su incoherencia y exclusión entre sí. Discusión a la que se adiciona la proveniente de la fundamentación y aplicación de los principios fundantes de las constituciones contemporáneas: necesidad, proporcionalidad y razonabilidad de la pena como límite al poder punitivo del Estado.

Por otro lado, un 'supuesto derecho penal' de carácter peligrosista, en el que no se persigue el acto del sujeto, ni se considera al hombre como sujeto de derechos; de manera que no requiere garantizar nada en su favor y posibilita el ejercicio del poder de castigar sin controles, en aras de que con la pena se obtenga el restablecimiento de la norma quebrantada, el mantenimiento de la vigencia de la norma, pero de la norma subordinada, es decir, la norma penal y no la norma fundante, la norma constitucional. 'Supuesto derecho' que en virtud de su carácter antigarantista no comparte las características y particularidades del ordenamiento jurídico $\mathrm{y}$, por consiguiente, no puede ser consi-

50. Ver Lesch, Heiko. La función de la pena. Bogotá: Universidad Externado de Colombia, 2000, pág. 19 y ss.

51. Roxin, Claus. Sentido y límites de la pena estatal. En Problemas básicos de derecho penal. Madrid, 1976, págs. 12 y ss.

52. Ibíd., pág. 17 y ss.

53. Ibíd., pág. 16.

54. JAKoBs, Günther. Sobre la teoría de la pena. Bogotá: Universidad Externado de Colombia, 1998, pág. 12. Sobre las críticas a la teoría de la prevención general positiva ver: Arboleda Ripold, Fernando. La teoría de la pena de Günther Jakobs. En Dogmática y criminología. Bogotá: Editorial Legis. 
derado 'derecho' ${ }^{55}$, crítica que se ha pretendido sortear bajo la propuesta de realizar, frente a esta legislación contraria a los mandatos constitucionales, una elaboración 'relajada' o 'flexible' del Estado de Derecho, el cual se pretende replantear o definir de manera que admita o armonice la flexibilidad que representa un retorno discursivo al Estado totalitario y el abandono de la garantía de los derechos humanos ${ }^{56}$.

\section{Conclusión}

La historia muestra que la antinomia derecho de castigar y derechos del hombre ha existido desde tiempos remotos y sigue sin resolverse, pues convivimos con un gran espacio de manipulación a través de discursos que inclinan la balanza en torno a alguna de las dos, y en los que la pena sigue siendo un "mal necesario", pero tal "necesidad" cobra una significación distinta en cada momento. Mientras el ejercicio del poder de castigar se acerca a la garantía de los derechos del hombre y los modelos de Estado que se fundamentan en ellos, la necesidad de pena cobra relevancia como límite al poder de castigar, pero a medida que se aleja de ellos y se acerca a los modelos totalitarios se diluye su propiedad controladora, al dar paso a discursos permisivos de penas arbitrarias.
Así, el problema al cual nos enfrentamos actualmente es que, una vez vistos los horrores a los que se ha llegado a través de los discursos que se apartan del respeto de los derechos humanos, encendamos la alarma que nos indica que es necesario reflexionar sobre qué contenido se le da a los conceptos que los conforman y hacia dónde se dirigen. Así como también, qué significado se otorga a la acepción “terrorismo de Estado" y qué posición se asume frente a ese filtro de legitimidad que de tiempos remotos planteó Sócrates en su diálogo con Critón: "de ningún modo se debe retribuir con injusticia al que comete injusticia, puesto que en ningún caso se debe cometer injusticia" ${ }^{57}$ de tal forma que la espiral no siga dando giros y pueda tener un final anclado en el respeto y garantía de los derechos fundamentales. $\bullet$

\section{BIBLIOGRAFÍA}

Arboleda Ripoll, Fernando. La teoría de la pena de Günther Jakobs. En: Dogmática y criminología. Bogotá: Editorial Legis.

Beccaria, Cesare. De los delitos y de las penas. Bogotá: Universidad Externado de Colombia, 1994.

Bentham, Jeremías. Teoría de las penas y de las recompensas. Libro I, Cap. I. París en casa de Masson e hijo: Imprenta de E. Pochard, 1826.

55. Zaffaroni, Raúl. Ob. Cit., pág. 9. Rafecas, Daniel Eduardo. Una aproximación al concepto de garantismo penal. En: http://www. catedrahendler.org/material_in.php?id=3

56. Al respecto, JAскоBS, Günther. Ponencia: “Coacción y personalidad. Reflexiones sobre una teoría de las medidas complementarias a la pena”, presentada en el Simposio de Derecho Penal Argentino Alemán en la Universidad de Buenos Aires, el 14 de diciembre de 2007. Sin publicar.

57. Platón. Critón. Traducción directa, ensayo preliminar y notas de Conrado Eggers Lan. 2 ed. Buenos Aires: Eudeba, 1996, págs. 145 y ss. 
Bustos Ramírez, Juan. Introducción al derecho penal. Bogotá: Temis, 1994.

Carmignani, Giovanni. Elementos de Derecho Criminal. Bogotá: Editorial Temis, 1979.

Cattaneo, Mario A. Carl Schmitt y Roland Freisler: la doctrina penal del nacional-socialismo. En: http://www.uclm.es/aidp/pdf/barbero 1/8. pdf. Disponible a 30 de diciembre de 2007.

Córdoba Angulo, Miguel. Límites al poder punitivo en la nueva Constitución y pena de muerte. En: Revista Derecho Penal y Criminología. Universidad Externado de Colombia. Número 52.

Córdoba Roda, Juan. Culpabilidad y pena. España: Bosch, Casa Editorial, 1977.

De Vergottini, Giuseppe. Las transiciones constitucionales. Bogotá: Universidad Externado de Colombia, 2002.

Ferrajoli, Luigi. Derecho y Razón. Madrid: Editorial Trotta, 1996.

La pena en una sociedad democrática. En: La pena garantismo y democracia. Bogotá: Ediciones Jurídicas Gustavo Ibáñez, 1999.

Foucault, Michael. La verdad y las formas jurídicas. España: Gedisa, 2000.

Gómez Pavajeau, Carlos Arturo. Derecho penal y edad media. Bogotá: Giro editores Ltda., 2004.

Estudios de Dogmática en el nuevo código penal. Segunda parte. Bogotá: Ediciones Gustavo Ibáñez, 2004.

Lesch, Heiko. La función de la pena. Bogotá: Universidad Externado de Colombia, 2000.

JakobS, Günther. Sobre la teoría de la pena. Bogotá: Universidad Externado de Colombia, 1998.

Kramer, Heinrich y Sprenger Jacobus. Malleus Maleficarum. (El martillo de los brujos). Trad. Floreal Maza. Buenos Aires: Ediciones Orión, 1956.

Luzón PeÑa, Diego Manuel. La relación del merecimiento de pena y de la necesidad de pena con la estructura del delito. En: Fundamentos de un sistema europeo del derecho penal. Libro homenaje a Claus Roxin. Barcelona: J.M. Bosch Editor S.A.
Montesquieu. El espíritu de las leyes. Bogotá: Ediciones universales, 2001.

Naranjo Mesa, Vladimiro. Teoría constitucional e instituciones políticas. Bogotá: Temis, 1991.

Pavarini, Massimo. Controly dominación. México: Siglo veintiuno editores, 1983.

Platón. Critón. Trad. Conrado Eggers Lan. 2 ed. Buenos Aires: Eudeba, 1996.

RAFECAS, Daniel. El derecho penal frente al holocausto (a propósito de unas obras recientes de Francisco Muñoz Conde y de Enzo Traverso). En: http:// www.catedrahendler.org/material_in.php?id= 6\&PHPSESSID $=1$ f923ff 7 1b3d 1f 7a 4 b 1416578 $18022 \mathrm{~d} 1$

Rogmanosi, Giandomenico. Génesis del derecho penal. Bogotá: Temis, 1956.

Roxin, Claus. Culpabilidad y prevención en derecho penal. España: Reus S.A., 1981.

Política criminal y estructura del delito. Barcelona: PPU, 1992.

Sentido y límites de la pena estatal. En: Problemas básicos de derecho penal. Madrid, 1976.

Sandoval Huertas, Emiro. Penología, partes general y especial. Bogotá: Ediciones Jurídicas Gustavo Ibáñez, 1996.

Segura Ortega, Manuel. La situación del derecho penal y procesal en los siglos XVI y XVII. En: Historia de los derechos fundamentales. Tomo I. Madrid: Dikinson - Universidad Carlos III de Madrid, 1998.

Silva Sánchez, Jesús María. La expansión del derecho penal. Argentina: Editorial B de F., 2006.

Tomás y Valiente, Francisco. El derecho penal de la monarquía absoluta. Madrid: Tecnos, 1969.

Urbano Martínez, José Joaquín. La legitimidad del derecho penal. Bogotá: Universidad Externado de Colombia, 2001.

Velásquez Velásquez, Fernando. Manual de derecho penal. Bogotá: Temis, 2002.

ZaFfaroni, Eugenio Raúl. El enemigo en el derecho penal. Argentina: Ediar, 2006. 